\title{
Subset-directed antiviral treatment of I42 herpesvirus patients with chronic fatigue syndrome
}

This article was published in the following Dove Press journal:

Virus Adaptation and Treatment

24 May 2010

Number of times this article has been viewed

\author{
A Martin Lerner' \\ Safedin Beqaj ${ }^{2}$ \\ James T Fitzgerald ${ }^{3}$ \\ Ken Gill ${ }^{4}$ \\ Carol Gill ${ }^{4}$ \\ James Edington ${ }^{4}$
}

'Department of Medicine, William Beaumont Hospital, Royal Oak; ${ }^{2}$ Wayne State University School of Medicine, Detroit; ${ }^{3}$ Department of Medical Education, University of Michigan Medical School, Ann Arbor, Michigan; ${ }^{4}$ The Dr A Martin Lerner Chronic Fatigue Syndrome Foundation, Beverly Hills, Michigan, USA
Correspondence: A Martin Lerner 32804 Pierce Road, Beverly Hills, MI 48025, USA

Tel +I 2485409866

Fax +l 2485400139

Email amartinlerner@yahoo.com
Purpose: We hypothesized that chronic fatigue syndrome (CFS) may be caused by single or multiple Epstein-Barr virus (EBV), cytomegalovirus (HCMV), or human herpesvirus 6 (HHV6) infection. To determine if CFS life-altering fatigue and associated findings including muscle aches, tachycardia at rest, chest aches, left ventricular dysfunction, syncope, and elevated herpesvirus serum antibody titers are reversed by long-term subset-directed valacyclovir and/or valganciclovir.

Patients and methods: Data were collected at physician visits every 4-6 weeks from 142 CFS patients at one clinic from 2001 to 2007. To be included in this study, patients had to be followed for at least six months. The data captured included over 7000 patient visits and over 35,000 fields of information. Severity of fatigue was monitored by a validated Energy Index Point Score ${ }^{\circledR}\left(\right.$ EIPS $\left.^{\circledR}\right)$. Baseline and follow-up serum antibody titers to EBV, HCMV, and HHV6, as well as coinfections with Borrelia burgdorferi, Anaplasma phagocytophila, Babesia microti, and antistreptolysin O, 24-hour ECG Holter monitors, 2D echocardiograms, cardiac dynamic studies, symptoms, and toxicity were captured and monitored. International criteria for CFS plus a specifically designed CFS diagnostic panel were used.

Results and conclusions: The Group A herpesvirus CFS patients (no coinfections) returned to a near-normal to normal life $(P=0.0001)$. The long-term EIPS value increased (primary endpoint, $P<0.0001$ ) with subset-directed long-term valacyclovir and/or valganciclovir therapy. Secondary endpoints (cardiac, immunologic, and neurocognitive abnormalities) improved or disappeared. Group B CFS patients (herpesvirus plus coinfections) continued to have CFS.

Keywords: valacyclovir, valganciclovir, treatment, chronic fatigue syndrome, CFS, Energy Index Point Score ${ }^{\circledR}$, EIPS $^{\circledR}$

\section{Introduction}

Chronic fatigue syndrome (CFS) is a life-altering illness affecting women to men in a ratio of $4: 1,{ }^{1-3}$ for which there is no evidence-based etiology or treatment. ${ }^{4-7}$ An association of CFS with an infectious gamma retrovirus XMRV, previously found in high-grade malignant prostate cancers, has been reported. ${ }^{8}$ This xenotropic virus is similar to Maloney murine leukemia and the sarcoma virus in rodent, feline, and primate species. XMRV possesses a slow mechanism for oncogenesis, and its course does not always lead to cancer. ${ }^{8,9}$ However, the XMRV report requires confirmation. ${ }^{10}$

Cardiac, immunologic, radiographic, and genetic abnormalities are present in CFS patients. ${ }^{11-21}$ We hypothesized that CFS is caused by Epstein-Barr virus (EBV), cytomegalovirus (HCMV), and human herpesvirus 6 (HHV6) in single or multiple virus infection. ${ }^{22}$ This suggests CFS patients continue EBV, HCMV, and HHV6 herpesvirus replication, and do not achieve the viral latency necessary for 
recovery. ${ }^{23-25}$ We propose that early and middle herpesvirus (EBV, HCMV, HHV6) gene products to about the fiftieth gene of these complex viruses, containing over 200 openreading frames, are synthesized without achieving complete virus formation. ${ }^{26}$ We now test this hypothesis with the nucleosides valacyclovir for a suspected EBV CFS subset and valganciclovir for suspected HCMV or HHV6 CFS subsets. We report long-term benefit, assessed by the validated severity of an illness metric, the Energy Index Point Score ${ }^{\circledR}\left(\right.$ EIPS $\left.^{\circledR}\right) .{ }^{27}$ Seventy-nine of 106 (74.5\%) CFS patients returned to a near-normal to normal life (primary endpoint). Secondary endpoints of cardiac, immunologic, and neurocognitive abnormalities improved or disappeared. The data support the paradigm that CFS illness is a herpesvirus infection.

Group A CFS patients have EBV, HCMV, and HHV6 in single or multiple infection without coinfection. Group B CFS patients are similar to Group A, but with coinfections, tick-borne Borrelia burgdorferi, Babesia microti, Anaplasma phagocytophila, and/or adult rheumatic fever. Our research questions were whether subset-directed antiviral therapy to single and multiple herpesvirus CFS patient groups causes a significant change in EIPS; what percentages of groups A and B CFS patients have EBV, HCMV, and/or HHV6 infection; whether long-term valacyclovir (for EBV) and valganciclovir (for HCMV, HHV6) treatment can cause lasting improvement in EIPS values for CFS patients; if long-term valacyclovir and/or valganciclovir are free of deleterious effects to complete blood count (CBC), aspartate aminotransferase (AST), alanine aminotransferase (ALT), and creatinine; whether single and coinfection CFS subsets respond similarly; and if there are identifiable demographics of Group A CFS patients who are "responders" and "nonresponders" to antiviral therapy?

\section{Methods}

\section{Data collection process}

The work process flow for this systematic review included initial selection screening, data collection and validation, and data analysis (Figure 1). Patient data were captured using a predefined set of data points. Demographics and each office visit were recorded by date, including presence of positive EBV, HCMV, and HHV6 serum antibody titers, specific antiviral therapy with dosage, change in antiviral treatment and reason for change, EIPS, 24-hour ECG Holter monitoring (HM), and toxicities. Serum antibody titers to B. burgdorferi, B. microti, A. phagocytophila, and antistreptolysin $\mathrm{O}$ were assessed. Each patient was assigned a blinded numerical number, and data were entered into a Microsoft Office Access 2007 database that had been specifically designed for this study. A $100 \%$ audit was performed ( $>7000$ office visits and $>35,000$ fields of data). Data were collected and analyzed by nonphysician, information-experienced professionals. Microsoft Office Access 2007 was used for data entry, validation, and storage. The blinded patient number was maintained throughout the study. This study was approved by the Human Investigation Committee at William Beaumont Hospital.

\section{Study selection}

International criteria for diagnosis of CFS were used. ${ }^{2}$ Intravenous ganciclovir (1997) and oral valacyclovir (2002, 2007) had been explored in earlier small clinical trials. ${ }^{28-30}$

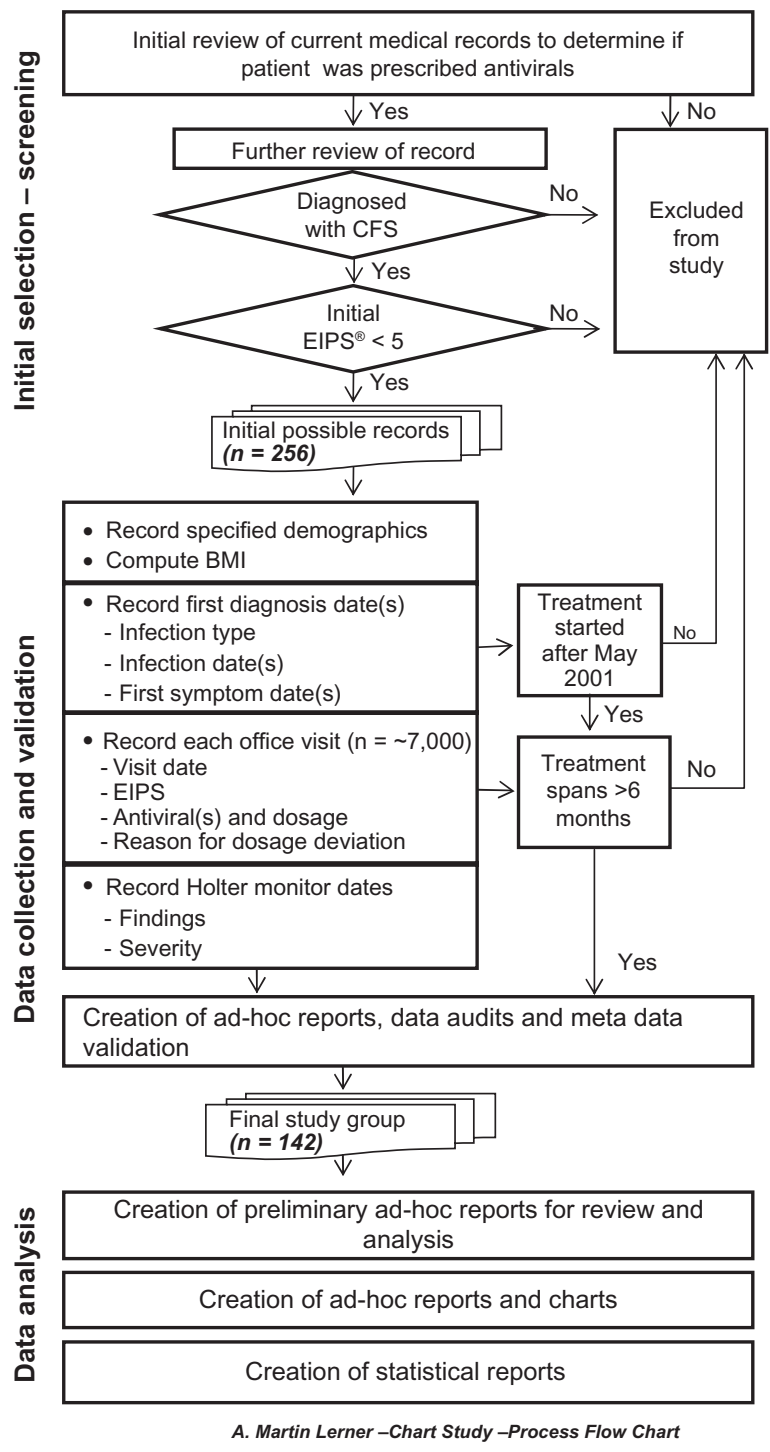

Figure I Work process flow systematic review of herpesvirus in CFS patients, 200I-2007.

Abbreviations: BMI, body mass index; CFS, chronic fatigue syndrome; EIPS, Energy Index Point Score. 
Oral valganciclovir became available for clinical use in 2000 , and was then used in place of intravenous ganciclovir. The Dr A Martin Lerner Chronic Fatigue Syndrome Foundation was organized in 2007 to support research determining the possible value of specific subset-directed antiviral treatment of CFS.

Active charts of CFS patients (EIPS $\leq 5$ ) who began and continued antiviral medications at this clinic from 01 May 2001 to December 2007 for at least six months were randomly selected for inclusion in this study. ${ }^{27}$ Serologic evidence for EBV, HCMV, and HHV6 were identified. CFS patients were considered to have active EBV infection if there were elevated enzyme-linked immunosorbent assay (ELISA) serum antibodies to EBV IgM viral capsid recombinant peptide antigen VCA p18 (Diasorin, Stillwater, MN) and/or EBV early antigen EA-D, a $47 \mathrm{kDa}$ recombinant polypeptide..$^{23,29,30}$ HCMV infection was identified by elevated serum antibody titers to human fibroblast lysate HCMV strain AD69, IgM, or IgG by ELISA tests and elevated Copalis light-scatter HCMV IgM p52 recombinant protein, UL44, and HCMV CM2, UL44, and part UL57 recombinant protein. ${ }^{24,25}$ HHV6 infection was identified by elevated IgM and IgG serum antibody titers $\geq 160$ (LabCorp, Dublin, $\mathrm{OH}){ }^{31}$ CFS patients had abnormal 24-hour HM recordings. ${ }^{12,15,16}$ When baseline abnormal resting standard ECG and abnormal recurrent oscillating T-waves (flat, inverted) on $\mathrm{HM}$ recordings were present, myocardial perfusion studies to exclude coronary artery disease and radionuclide ventriculography (MUGA) by bicycle protocol stress studies were performed. ${ }^{14,16}$ Seven randomly selected CFS patients had cardiac muscle biopsies. ${ }^{15}$ Two patients had postcardiac biopsy bleeding.

There were $106 \mathrm{CFS}$ patients who had negative IgM and $\mathrm{IgG}$ serum antibody titers to B. burgdorferi by Western blot and ELISA test, with antistreptolysin 0 titers $<400$ units, and negative serum $\operatorname{IgM}$ and $\operatorname{IgG}$ antibody titers to B. microti and A. phagocytophila. These patients were categorized as Group A CFS. An additional 36 CFS patients had elevated serum antibody titers to B. burgdorferi, B. microti, A. phagocytophila, or antistreptolysin $0>400$, and comprised Group B CFS.

\section{Severity of fatigue}

The EIPS is a validated metric determining severity of CFS illness. ${ }^{27}$ Patients were evaluated by EIPS with consensus of physician and patient. An EIPS of 0-5 is diagnostic of CFS. At EIPS values 6-10, patients no longer have CFS. An effect size of 0.8 is significant. A CFS patient was considered a "responder" to antiviral treatment if the change in EIPS effect

\begin{tabular}{|c|c|}
\hline 0 & Bedridden, up to bathroom only \\
\hline 1 & $\begin{array}{l}\text { Out of bed } 30-60 \text { minutes a day (sitting in } \\
\text { chair is out of bed) }\end{array}$ \\
\hline 2 & $\begin{array}{l}\text { Out of bed sitting, standing, walking 1-2 hours } \\
\text { per day }\end{array}$ \\
\hline 3 & $\begin{array}{l}\text { Out of bed sitting, standing, walking } 2-4 \text { hours } \\
\text { per day }\end{array}$ \\
\hline 4 & $\begin{array}{l}\text { Out of bed sitting, standing, walking } 4-6 \text { hours } \\
\text { per day }\end{array}$ \\
\hline 5 & $\begin{array}{l}\text { Perform with difficulty sedentary job } 40 \text { hours a } \\
\text { week, daily naps }\end{array}$ \\
\hline \multicolumn{2}{|c|}{ Recovery } \\
\hline 6 & $\begin{array}{l}\text { Daily naps in bed, may maintain a } 40 \text {-hour } \\
\text { sedentary work week plus light, limited } \\
\text { housekeeping and/or social activities }\end{array}$ \\
\hline 7 & $\begin{array}{l}\text { No naps in bed. Up 7:00 am to } 9: 00 \mathrm{pm} \text {. Able to } \\
\text { work a sedentary job plus light housekeeping }\end{array}$ \\
\hline 8 & $\begin{array}{l}\text { Full sedentary workweek, no naps, some social } \\
\text { activities plus light exercise }\end{array}$ \\
\hline 9 & $\begin{array}{l}\text { Same as } 8 \text { above plus exercise approximately } \\
1 / 2 \text { to } 2 / 3 \text { normal without excessive fatigue, } \\
\text { awakens next morning refreshed }\end{array}$ \\
\hline 10 & Normal \\
\hline
\end{tabular}

Figure 2 Energy Index Point Score ${ }^{\circledR}$ : A functional capacity measurement tool for CFS patients. The Energy Index Point Score ${ }^{\circledR}\left(\right.$ EIPS $\left.^{\circledR}\right)$ chart provides the severity of patient fatigue. A change in EIPS level of $I$ is a large significant change. The EIPS level is determined by agreement of physician and patient with the EIPS chart easily available for viewing at outpatient visits. As the EIPS level increases, CFS symptoms lessen and disappear. The EIPS system can be used in four easy steps: post the EIPS chart in examining room; ask the patient to evaluate his/her level of activity based on the prior two weeks; question the patient's EIPS evaluation; record and track the EIPS level; report every 6-12 weeks. Copyright (C) 2002 Prous Science, S.A. All rights reserved. Adapted with permission from Lerner AM, Beqaj SH, Deeter RG, et al. A six-month trial of valacyclovir in the Epstein-Barr virus subset of chronic fatigue syndrome: Improvement in left ventricular function. Drugs of Today. 2002; 38(8):549-561.

size was $\geq 1$. A CFS patient was considered a "nonresponder" to antiviral treatment if the effect size was $<1$ (Figure 2).

\section{Valacyclovir (or famciclovir) for EBV infection}

Valacyclovir and famciclovir are oral prodrugs which are absorbed as acyclovir and penciclovir, respectively, and effectively inhibit EBV thymidine kinase. ${ }^{32,33}$ The EBV ID ${ }_{50}$ for valacyclovir is $1.1-4.4 \mu \mathrm{g} / \mathrm{L}$. Its bioavailability is increased by food. Valacyclovir may cause diarrhea, so famciclovir was then substituted if necessary. Both valacyclovir and 
famciclovir were given as $1 \mathrm{gm}(14.3 \mathrm{mg} / \mathrm{kg})$ every six hours. When the patient weighed $\geq 79.5 \mathrm{~kg}, 1500 \mathrm{mg}$ valacyclovir (or famciclovir) was given every six hours. Maximum acyclovir levels are present after 90-120 minutes (7.9-21 $\mu \mathrm{g} / \mathrm{mL}) .{ }^{29}$ Valacyclovir is excreted by renal glomerular filtration and tubular secretion. The elimination half-lives of acyclovir and penciclovir are in the range of 1.5-6 hours. Patients were instructed to drink at least $1500 \mathrm{~mL}$ of water daily to avoid valacyclovir-induced renal calculi. At the physician's discretion, cimetidine (400 mg every 12 hours) and/or probenecid (500 mg every 12 hours) which inhibit(s) acyclovir tubular secretion were given to increase acyclovir serum levels. ${ }^{32,34}$ Valacyclovir and famciclovir do not effectively inhibit HCMV or HHV6 multiplication. In order to continue therapy, normal $\mathrm{CBC}$, platelet count, aminotransferases, and urinalysis were required at physician visits every 4-6 weeks.

\section{Valganciclovir for HCMV and/or HHV6 infection}

The valganciclovir ID $_{50}$ for HCMV and HHV6 is $0.2-$ $2.8 \mu \mathrm{g} / \mathrm{mL}$. The $\mathrm{ID}_{50}$ for ganciclovir versus EBV is $0.5 \mu \mathrm{g} / \mathrm{mL} .^{35}$ In this study valganciclovir was used for CFS patients with suspected HCMV or HHV6 infections. Valganciclovir is efficiently absorbed as ganciclovir, inhibiting human bone marrow progenitor cells and lymphocyte blastogenesis. After 0.5-1.0 gm doses, the average peak valganciclovir concentration $\left(\mathrm{C}_{\max }\right)$ is $6.1 \mu \mathrm{g} / \mathrm{mL}$. Valganciclovir was also given after meals, thereby increasing its bioavailability. Valganciclovir was started at $450 \mathrm{mg}$ once daily in the morning after food for three days, and then continued as two in the morning for three days; and finally given, two in the morning followed by $450 \mathrm{mg} 12$ hours later as a continuing dose. If elevated aminotransferase(s) occurred, valganciclovir was withheld for 1-2 weeks until serum transaminases were normal. Valganciclovir was then continued $900 \mathrm{mg}$ once daily. If the patient weighed $>91 \mathrm{~kg}$, $900 \mathrm{mg}$ valganciclovir was given every 12 hours.

\section{Atenolol and fludrocortisone acetate}

Resting tachycardia with orthostatic hypotensive syncope were treated with atenolol 12.5-50 mg every 12 to 24 hours. ${ }^{11,12,14,15}$ After beginning atenolol, the 24-hour HM recording was repeated seven days later to confirm that tachycardia had decreased. When needed, digoxin was also used to decrease tachycardia. For associated orthostatic hypotension, $0.1 \mathrm{mg}$ fludrocortisone acetate every 12 to 24 hours was administered. As the EIPS value rose and symptoms diminished, atenolol, digoxin, and fludrocortisone were discontinued.

\section{Treatment of coinfections}

Patients with elevated serum antibody titers to B. burgdorferi, anaplasmosis, babesiosis, or adult rheumatic fever were treated according to the clinical practice guidelines of the Infectious Diseases Society of America, the American Heart Association, and the World Health Organization. ${ }^{36,37}$ Patients with elevated serum antibody titers to B. burgdorferi were given ceftriaxone 1-2 gm intravenously every 12 hours. A. phagocytophila infection was treated with doxycycline $100 \mathrm{mg}$ every 12 hours orally or intravenously. B. microti infection was treated orally with atovaquone $750 \mathrm{mg}$ and azithromycin $500 \mathrm{mg}$ every 12 hours. Coinfections were treated for 30 days and then assessed.

\section{Toxicity}

At 4-6 week visits, recorded entries were made for abnormal white blood cells, platelet counts, aminotransferases, participation in a smaller, randomized, blinded, placebo-controlled trial, weight gain or loss, substitution of famciclovir for valacyclovir, and any changes in dosage of valganciclovir, valacyclovir, or famciclovir. ${ }^{30}$

\section{Qualitative Holter monitor assessments}

Twenty-four hour HM recordings were evaluated qualitatively for simple counts of abnormalities and severity, (mild, 1 point; medium, 2 points; or severe, 3 points). Tachycardia at rest $(>100$ per minute) was assessed as mild $<6$ hours/ 24 hours;medium $>6$ and $\leq 10$ hours/24 hours; or severe $>10$ hours/24 hours). Oscillating abnormal T-wave flattenings and T-wave inversions were evaluated as mild (occasional), medium (intermittent), or severe (frequent) and given severity point scores of 1, 2, or 3, respectively. Deep inverted T-waves, multiple and multifocal ventricular premature contractions, and bigeminal rhythms were evaluated by count and severity. Thus, HM recordings had two numeric evaluations, ie, a simple numeric count of types of abnormality and a severity score. For example, a patient with an HM showing T-wave flattening (severity score 1), mild supraventricular tachycardia (severity score 1), but with no inverted T-waves would equate to a severity score of 2 with an abnormality count of 2. Another patient with an HM and moderate supraventricular tachycardia (severity score 2) "abnormal count 1", and both moderate numbers of oscillating T-wave flattenings (severity score 2) "abnormal count 1", multifocal ventricular premature contractions (severity score 2) "abnormal count 1 ", and a bigeminal rhythm (severity score 3 ) "abnormal count 1." The latter HM would have a total severity score of 9 and an abnormal simple occurrence count of 4 . 


\section{Summary measures}

For Group A CFS in 106 patients, gender distribution for age, BMI, duration of illness prior to treatment, duration of treatment, baseline EIPS value, last EIPS value, and EIPS delta value were determined by t-tests (two-tailed). Change between overall baseline EIPS value and overall last EIPS value was examined by a paired t-test (two-tailed). Differences in gender distribution by herpesvirus category (single or multiple) were examined by Fisher's exact test (two-tailed). Pearson chi-square analyses were used to examine gender distribution by subset classification within the herpesvirus category. Change in EIPS value was examined by multivariate analysis of variance with repeated measures. CFS patient responder and non-responder differences by gender and by herpesvirus category were examined by the Fisher's exact test (two-tailed). Differences between responders and nonresponders for age, BMI, CFS duration prior to antiviral therapy, duration of antiviral therapy, initial EIPS value, and last EIPS value were examined by t-tests (two-tailed). Numbers of Group B CFS patients were too small for statistical analysis. Microsoft Office Excel 2007 and SAS Version 8.0.1 were used for reporting and statistical analysis, respectively.

\section{Results}

\section{Demographics of Group A CFS patients}

There were 106 Group A CFS patients treated with antiviral medicines (Table 1), of whom $73 \%$ were female and $27 \%$ were male. Mean age was 46.2 years and mean BMI was

Table I Demographics of I 42 patients with CFS, 200I-2007

\begin{tabular}{|c|c|c|c|c|c|}
\hline \multirow[t]{2}{*}{ Patients } & \multirow{2}{*}{$\begin{array}{l}\text { Group A patients } \\
(n=106)\end{array}$} & \multirow[t]{2}{*}{$P$ value } & \multicolumn{2}{|l|}{ Group B } & \multirow{2}{*}{$\begin{array}{l}\text { Patients without } \\
\text { B.b. }(n=I 0)\end{array}$} \\
\hline & & & All patients $(n=36)$ & B.b. $(n=26)$ & \\
\hline Women & 77 patients (73\%) & & 28 patients $(77.8 \%)$ & 23 patients (63.8\%) & 5 patients $(13.9 \%)$ \\
\hline Men & 29 patients (27\%) & & 8 patients (22.2\%) & 3 patients $(8.3 \%)$ & 5 patients $(13.9 \%)$ \\
\hline Age, all patients (mean \pm SEM) & $46.2+1.3$ years & & & & \\
\hline Age, women & $47.1 \pm 1.5$ years & $0.309^{\prime}$ & 44.2 years & 44.5 years & 43 years \\
\hline Age, men & $44.0 \pm 2.8$ years & & 40.9 years & 48.3 years & 36.4 years \\
\hline BMI, all patients (mean \pm SEM) & $26.4 \pm 0.5 \mathrm{~kg} / \mathrm{m}^{2}$ & & $26.5 \mathrm{~kg} / \mathrm{m}^{2}$ & $26.8 \mathrm{~kg} / \mathrm{m}^{2}$ & $25.7 \mathrm{~kg} / \mathrm{m}^{2}$ \\
\hline BMI, women & $26.6 \pm 0.6 \mathrm{~kg} / \mathrm{m}^{2}$ & $0.573^{\prime}$ & $26.4 \mathrm{~kg} / \mathrm{m}^{2}$ & $26.9 \mathrm{~kg} / \mathrm{m}^{2}$ & $24.1 \mathrm{~kg} / \mathrm{m}^{2}$ \\
\hline BMI, men & $26.0 \pm 0.6 \mathrm{~kg} / \mathrm{m}^{2}$ & & $26.7 \mathrm{~kg} / \mathrm{m}^{2}$ & $26 \mathrm{~kg} / \mathrm{m}^{2}$ & $27.1 \mathrm{~kg} / \mathrm{m}^{2}$ \\
\hline $\begin{array}{l}\text { All patients duration of } \\
\text { illness (mean } \pm \text { SEM prior to } \\
\text { treatment) }\end{array}$ & $4.8 \pm 0.5$ years & & 5.9 years & 4.7 years & 8.9 years \\
\hline $\begin{array}{l}\text { Duration of illness prior to Ist } \\
\text { antiviral treatment, women }\end{array}$ & $4.6 \pm 0.6$ years & $0.537^{\prime}$ & 4.5 years & 4.I years & 6.1 years \\
\hline $\begin{array}{l}\text { Duration of illness prior to Ist } \\
\text { antiviral treatment, men }\end{array}$ & $5.3 \pm 1.2$ years & & 10.8 years & 9.5 years & 11.6 years \\
\hline $\begin{array}{l}\text { All patients duration of antiviral } \\
\text { treatment (mean } \pm \text { SEM) }\end{array}$ & $2.4 \pm 0.2$ years & & 2.6 years & 2.6 years & 2.4 years \\
\hline $\begin{array}{l}\text { Duration of antiviral treatment, } \\
\text { women }\end{array}$ & $2.5 \pm 0.2$ years & $0.416^{\prime}$ & & & \\
\hline $\begin{array}{l}\text { Duration of antiviral treatment, } \\
\text { men }\end{array}$ & $2.2 \pm 0.3$ years & & & & \\
\hline $\begin{array}{l}\text { All patients baseline EIPS, } \\
(\text { mean } \pm \text { SEM })\end{array}$ & $4.2 \pm 0.1$ & & 3.8 & 4.0 & 3.4 \\
\hline Baseline, EIPS, women & $4.2 \pm 0.1$ & $0.695^{\prime}$ & & & \\
\hline Baseline, EIPS, men & $4.3 \pm 0.2$ & & & & \\
\hline $\begin{array}{l}\text { All patients last EIPS, patients } \\
\text { (mean } \pm \text { SEM) }\end{array}$ & $6.1 \pm 0.2$ & & 5.3 & 5.4 & 5.0 \\
\hline Last EIPS, women & $6.0 \pm 0.2$ & 0.3291 & & & \\
\hline Last EIPS, men & $6.3 \pm 0.3$ & & & & \\
\hline $\begin{array}{l}\text { All patients delta", } \\
\text { (mean } \pm \text { SEM) }\end{array}$ & $1.9 \pm 0.2$ & $<0.000 \mathrm{I}^{2}$ & 1.5 & 1.5 & 1.9 \\
\hline Delta*, women & $1.8 \pm 0.2$ & $0.378^{\prime}$ & & & \\
\hline Delta*, men & $2.1 \pm 0.3$ & & & & \\
\hline
\end{tabular}

Abbreviations: B.b., Borrelia burgdorferi; EIPS ${ }^{\circledR}$, Energy Index Point Score ${ }^{\circledR}$; CFS, chronic fatigue syndrome; SEM, standard error of measurement; BMI, body mass index. 't-test (two-tailed) to determine differences between men and women; ${ }^{2}$ paired t-test (two-tailed) to determine difference between baseline and last EIPS; "last EIPS minus first EIPS. Group B patients have multiple coinfections. Data listed are mean values. 
$26.4 \mathrm{~kg} / \mathrm{m}^{2}$. The patients had been ill for a mean of 4.8 years before their first clinic visit. The mean duration of antiviral therapy was 2.4 years. Baseline EIPS value was 4.2. The baseline EIPS value for women was 4.2 and the baseline EIPS value for men was 4.3. The last EIPS value for all patients was 6.1. The women's last EIPS value was 6.0, and the last men's EIPS value was 6.3 . This change between baseline and last EIPS is large $(P<0.0001)$. The effect size for the 106 patients was $+1.9(+1.8$ for women and +2.1 for men $)$.

\section{Herpesvirus subset classification, Group A CFS}

Among the 106 Group A patients with single herpesvirus subsets, there were 30 (28.3\%) EBV patients; 13 (12.3\%) HCMV patients, and two (1.9\%) HHV6 patients (Table 2). Among multiple herpesvirus CFS patients, there were 30 (28.3\%) EBV/HCMV patients, 12 (11.3\%) EBV/HCMV/ HHV6 patients, 14 (13.2\%) EBV/HHV6 patients, and five (4.7\%) HCMV/HHV6 patients.

Serial EIPS value changes from baseline and at 24 threemonth intervals for Group A CFS are shown in Table 3 and
Table 2 Single and multiple herpesvirus subsets in 106 Group A CFS patients

\begin{tabular}{llll}
\hline & Women $(\mathbf{n})$ & Men $(\mathbf{n})$ & Total patients \\
\hline $\begin{array}{l}\text { Single } \\
\text { herpesvirus CFS }\end{array}$ & & & \\
EBV & 20 & 10 & $30(28.3 \%)$ \\
HCMV & 8 & 5 & $13(12.3 \%)$ \\
HHV6 & 2 & 0 & $2(1.9 \%)$ \\
Total & 30 & 15 & $45(42.5 \%)$ \\
$\begin{array}{l}\text { Pearson } \\
\text { Chi-square } P=0.562\end{array}$ & & & \\
$\begin{array}{l}\text { Multiple } \\
\text { herpesvirus CFS }\end{array}$ & & & \\
$\begin{array}{l}\text { EBV/HCMV } \\
\text { EBV/HCMV/HHV6 }\end{array}$ & 7 & & \\
EBV/HHV6 & 11 & 6 & $30(28.3 \%)$ \\
HCMV/HHV6 & 5 & 5 & $12(11.3 \%)$ \\
$\begin{array}{l}\text { Total } \\
\text { Pearson } \\
\text { chi-square } P=0.258\end{array}$ & 47 & 3 & $14(13.2 \%)$ \\
\hline
\end{tabular}

Abbreviations: EBV, Epstein-Barr virus; HCMV, cytomegalovirus; HHV6, human herpesvirus 6; CFS, chronic fatigue syndrome.

Table 3 Mean EIPS ${ }^{\circledR}$ at three-month intervals for 106 Group A CFS patients including 79 (74.5\%) Group A "responders"”

\begin{tabular}{|c|c|c|c|c|c|c|c|}
\hline \multicolumn{4}{|c|}{ Total Group A $(n=106)$} & \multicolumn{4}{|c|}{ Group A “responders” $(n=79)$} \\
\hline $\begin{array}{l}\text { Three-month } \\
\text { intervals }\end{array}$ & Patients (n) & EIPS (mean) & EIPS (SD) & $\begin{array}{l}\text { Three-month } \\
\text { intervals }\end{array}$ & Patients (n) & EIPS (mean) & EIPS (SD) \\
\hline 0 & 106 & 4.21 & 0.87 & 0 & 79 & 4.36 & 0.80 \\
\hline I & 98 & 4.19 & 0.95 & I & 75 & 4.29 & 0.93 \\
\hline 2 & 104 & 4.44 & 1.21 & 2 & 77 & 4.70 & 1.19 \\
\hline 3 & 103 & 4.94 & 1.49 & 3 & 76 & 5.30 & 1.47 \\
\hline 4 & 96 & 5.49 & 1.50 & 4 & 73 & 5.84 & 1.40 \\
\hline 5 & 84 & 5.77 & 1.47 & 5 & 68 & 6.03 & 1.37 \\
\hline 6 & 78 & 6.06 & 1.46 & 6 & 65 & 6.44 & 1.24 \\
\hline 7 & 66 & 6.17 & 1.38 & 7 & 57 & 6.37 & 1.25 \\
\hline 8 & 59 & 6.25 & 1.25 & 8 & 53 & 6.35 & 1.20 \\
\hline 9 & 51 & 6.55 & 1.05 & 9 & 46 & 6.71 & 0.82 \\
\hline 10 & 47 & 6.83 & 1.15 & 10 & 44 & 6.94 & 0.98 \\
\hline II & 46 & 6.65 & 1.24 & 11 & 42 & 6.84 & 0.97 \\
\hline 12 & 40 & 6.26 & 1.40 & 12 & 37 & 6.35 & 1.33 \\
\hline 13 & 38 & 6.32 & 1.46 & 13 & 35 & 6.44 & 1.39 \\
\hline 14 & 38 & 6.54 & 1.36 & 14 & 36 & 6.63 & 1.32 \\
\hline 15 & 33 & 6.42 & 1.19 & 15 & 31 & 6.45 & 1.18 \\
\hline 16 & 30 & 6.59 & 1.20 & 16 & 28 & 6.70 & 1.03 \\
\hline 17 & 28 & 6.83 & 1.21 & 17 & 26 & 6.94 & 1.10 \\
\hline 18 & 27 & 6.52 & 1.40 & 18 & 25 & 6.64 & 1.34 \\
\hline 19 & 22 & 6.55 & 1.48 & 19 & 20 & 6.74 & 1.31 \\
\hline 20 & 18 & 6.69 & 1.86 & 20 & 16 & 6.89 & I.74 \\
\hline 21 & 14 & 6.40 & 1.47 & 21 & 12 & 6.64 & 1.40 \\
\hline 22 & 13 & 6.51 & 0.89 & 22 & 12 & 6.47 & 0.92 \\
\hline 23 & 13 & 6.70 & 0.88 & 23 & 12 & 6.72 & 0.92 \\
\hline 24 & 6 & 6.70 & 1.32 & 24 & 5 & 6.75 & 1.49 \\
\hline
\end{tabular}

Notes: ${ }^{+}$CFS "responder" is a CFS patient whose EIPS increases by at least one EIPS unit. All CFS patients included here received $\geq$six months of valacyclovir/valganciclovir treatment.

Abbreviations: CFS, chronic fatigue syndrome; EIPS, Energy Index Point Score; SD, standard deviation. 
Figure 3. In the total group of 106 patients, the baseline EIPS value was $4.2 \pm 0.87$ (standard deviation) and the last 72 -month EIPS value was $6.7 \pm 1.32(n=6)$. Seventy-nine (74.5\%) CFS patients had EIPS increases $\geq 1.0$. For the 79 CFS "responders," the mean baseline EIPS value was $4.36 \pm 0.8(\mathrm{n}=79)$, and the last 72 -month mean EIPS was $6.75 \pm 1.49(n=5)$.

\section{Demographics of Group A CFS responders and nonresponders}

Group A CFS responders and nonresponders were similar for sex, age, BMI, and distributions of single and multiple herpesvirus subsets (Table 4). However, these patients did differ in average duration of CFS illness prior to initiation of antiviral treatment ( 7.3 years for nonresponders versus 3.9 years for responders, $P=0.005$ ). Duration of antiviral therapy for responders averaged 2.70 years, but the nonresponders' duration of therapy was 1.53 years $(P<0.0001)$. Single and multiple herpesvirus CFS subsets responded equally well to antiviral therapy $(P=0.825)$. The delta EIPS for responders was $2.54(P<0.0001)$. EIPS improved in both single and multiple herpesvirus CFS patients. Twenty-one Group A single herpesvirus CFS patients had last EIPS values 7-9, and 27 Group A multiple herpesvirus CFS patients had last EIPS values 7-9.

Table 4 Demographics of 106 Group A herpesvirus CFS patients, 200I-2007

\begin{tabular}{|c|c|c|c|}
\hline & Responders & $\begin{array}{l}\text { Non } \\
\text { responders }\end{array}$ & $P$ value \\
\hline Number of patients & 79 & 27 & \\
\hline Females & 58 & 19 & $0.805^{\prime}$ \\
\hline Males & 21 & 8 & \\
\hline Age (years) & 45.5 & 48.4 & $0.347^{2}$ \\
\hline BMI $\left(\mathrm{kg} / \mathrm{m}^{2}\right)$ & 26.1 & 27.2 & $0.353^{2}$ \\
\hline $\begin{array}{l}\text { Mean duration of CFS } \\
\text { prior to antiviral therapy } \\
\text { (years) }\end{array}$ & 3.9 & 7.3 & $0.005^{2}$ \\
\hline $\begin{array}{l}\text { Single herpesvirus } \\
\text { subset (patients) }\end{array}$ & $\begin{array}{l}33 \\
(41.7 \%)\end{array}$ & $\begin{array}{l}12 \\
(44.4 \%)\end{array}$ & $0.825^{\prime}$ \\
\hline $\begin{array}{l}\text { Multiple herpesvirus } \\
\text { subset (patients) }\end{array}$ & $\begin{array}{l}46 \\
(58.3 \%)\end{array}$ & $\begin{array}{l}15 \\
(55.6 \%)\end{array}$ & \\
\hline $\begin{array}{l}\text { Mean duration of } \\
\text { antiviral therapy (years) }\end{array}$ & 2.70 & 1.53 & $0.00 \mathrm{I}^{2}$ \\
\hline Mean first EIPS & 4.34 & 3.81 & $0.006^{2}$ \\
\hline Mean last EIPS & 6.88 & 3.73 & $<0.00 \mathrm{I}^{2}$ \\
\hline $\begin{array}{l}\text { Difference, EIPS } \\
\text { associated with } \\
\text { antiviral therapy }\end{array}$ & 2.54 & -0.08 & $<0.0001^{3}$ \\
\hline
\end{tabular}

Abbreviations: CFS, chronic fatigue sydrome; EIPS ${ }^{\circledast}$, Energy Index Point Score ${ }^{\circledast}$. 'Fisher's exact test (two-tailed); ${ }^{2}$-test (two-tailed); ${ }^{3}$ multivariate analysis of variance with repeated measures.

\section{Demographics of Group B CFS patients and changes in EIPS}

Of 36 Group B CFS patients, 26 had elevated serum IgM or IgG, Western Blot or ELISA antibody titers to B. burgdorferi, with/without elevated serum antibody titers to Babesia or Anaplasma, or antistreptolysin O titers $>400$, and 10 patients did not have elevated Western Blot or ELISA IgM or IgG B. burgdorferi serum antibody titers, but did have elevated serum antibody titers to Babesia and/or Anaplasma and/or antistreptolysin O titers $>400 .{ }^{37}$ At first visits, Group B CFS patients were 43-48 years old and their BMI was $25.7-27.1 \mathrm{~kg} / \mathrm{m}^{2}$. Group B CFS patients had been ill for a mean of 5.9 years; Group B with B. burgdorferi had been ill for a mean of 4.7 years and those with no B. burgdorferi infection had been ill for 8.9 years. In all CFS patients in the Group B subset, men had been ill for longer than women. Baseline subset EIPS values were 3.1-4.0. After a mean 2.6 years of directed treatment, the last mean EIPS value was 5.3, thereby continuing a CFS diagnosis.

Among the 36 Group B CFS patients, 26 (72.2\%) had elevated serum titers to $B$. burgdorferi. There were 22 Group B CFS patients with EBV coinfection, 13 with HCMV coinfections, and 12 with HHV6 coinfections. Ten Group B CFS patients had no coinfecting $B$. burgdorferi, but included five EBV coinfections, seven HCMV coinfections, and five HHV6 coinfections. CFS Group B patients without B. burgdorferi included one patient with an elevated serum antibody titer to B. microti, two with elevated serum antibody titers to $A$. phagocytophila, and two with antistreptolysin 0 titers $>400$.

\section{EIPS changes at baseline and at three- month intervals for Group B CFS patients}

Baseline EIPS values for all Group B CFS subsets were similar, ie, 3.78 (for all 36 patients), 3.95 (for 26 patients with B. burgdorferi infection), and 3.35 (for 10 patients without B. burgdorferi infection). The last mean three-month EIPS values for these three subsets of Group B CFS patients were somewhat increased at 5.28, 5.39, and 4.97, respectively. However, at completion of the study, the three Group B CFS subsets continued to meet criteria for CFS diagnosis. Improvement was small.

\section{ECG Holter monitor recordings}

Of 104 Group A CFS patients with baseline HMs and follow-up HMs $\geq$ six months later, 92 (88.5\%) had abnormal baseline HM recordings. ${ }^{12,15}$ There were 77 (74\%) with abnormal oscillating T-wave flattening, 46 (44.2\%) with 


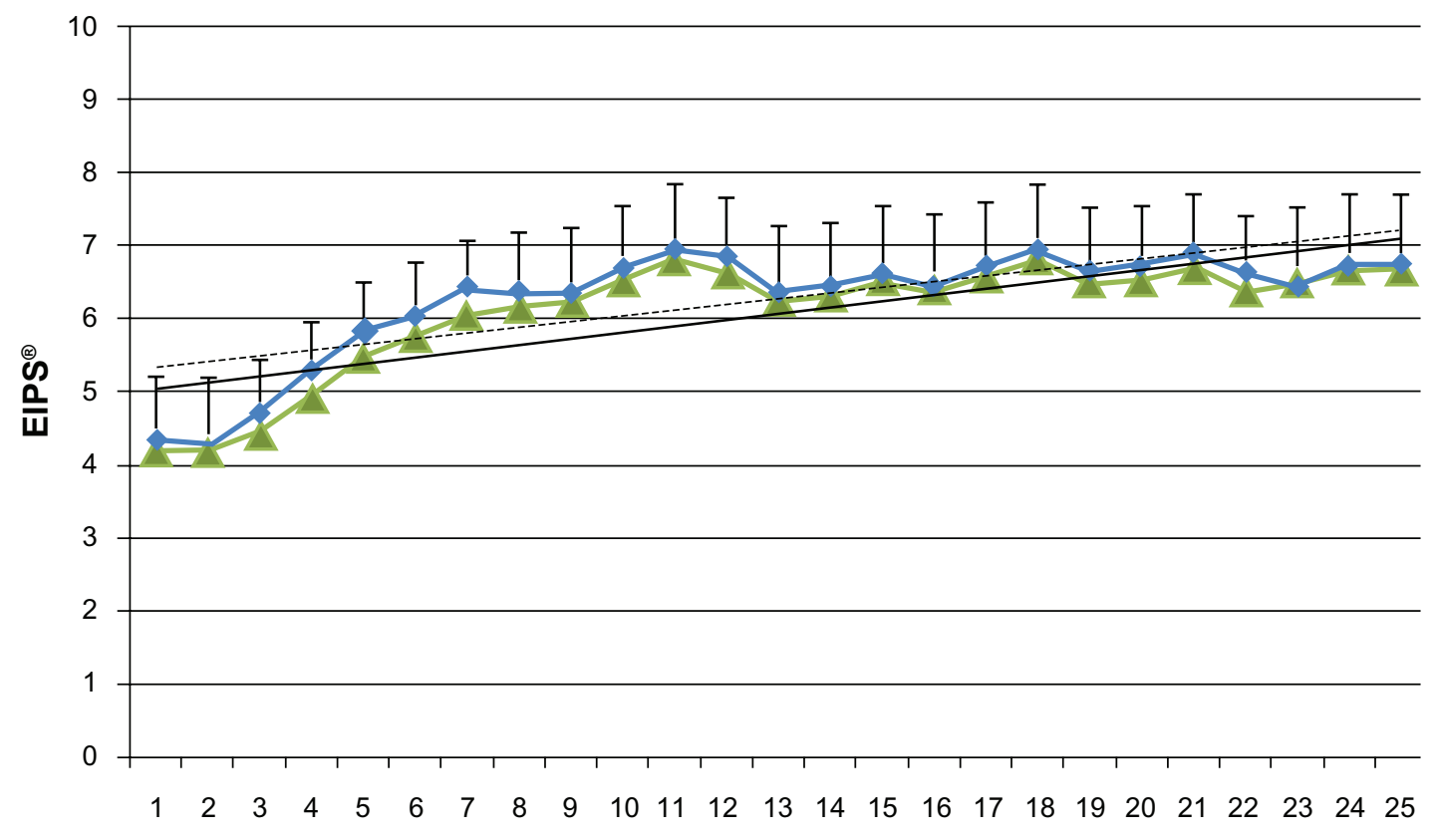

Three-month intervals

\section{Legend}
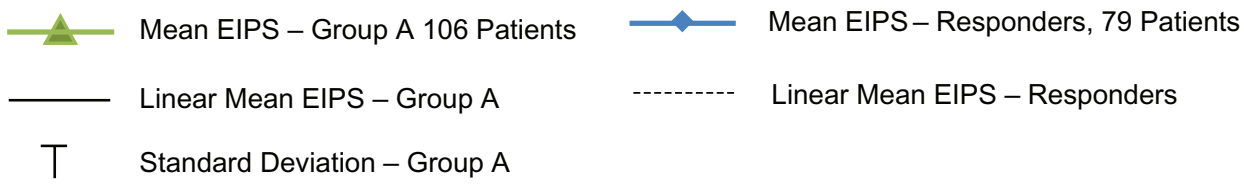

Figure 3 Mean increase in EIPS ${ }^{\circledR}$ of I06 Group A CFS patients treated with subset-directed antiviral nucleosides, $2001-2007$ at a single clinic.

abnormal oscillating T-wave inversions, and 47 (44.5\%) with resting tachycardia. These abnormal HM findings in CFS patients with no coronary artery disease, hypertension, or abnormal electrolyte abnormalities are a biomarker of CFS cardiomyopathy. ${ }^{12,15,16}$ Severity scores and abnormal data counts improved with valacyclovir/valganciclovir, but did not return to normal.

There were 25 Group B CFS patients with baseline and repeat HMs after six months of treatment. All of these patients had baseline abnormal HMs. Of Group B CFS patients, $22(88 \%)$ had abnormal oscillating T-wave flattening and 12 patients each (48\%) had abnormal oscillating T-wave inversions and resting tachycardia.

\section{Toxicity}

After beginning valacyclovir (or famciclovir) or valganciclovir there were two to 10 weeks with worsening initial symptoms, decreased EIPS, and increased syncope, palpitations, chest pain, and muscle pain. These transiently worsening symptoms are Jarisch-Herxheimer reactions. At these times CFS patients were usually afebrile and CBC, AST, ALT, and creatinine remained normal. No patient had serious toxicity. Transient increases in aminotransferases were seen with valganciclovir. Aminotransferase abnormalities resolved with modifications in administration of valganciclovir. There was no serious toxicity among groups A or B CFS patients. Fourteen Group A CFS patients with EBV received famciclovir for a mean of 0.88 years. The mean baseline EIPS value for these patients was 3.9, and the 24 three-month interval EIPS value was 5.89 for the patients, all of whom received valacyclovir for portions of their antiviral treatment. The value of famciclovir in CFS illness cannot be estimated from these data.

\section{Discussion}

We describe a CFS illness exemplifying a conflict between a complex system and attempts at reductionism. ${ }^{38} \mathrm{CFS}$ illness is divided into Group A herpesvirus (EBV, HCMV, HHV6) without coinfection and Group B herpesvirus CFS with coinfection(s). Coinfections are, remarkably, 
tick-borne Lyme disease, babesiosis and anaplasmosis, as well as non-tick-borne adult rheumatic fever. Long-term valacyclovir and/or valganciclovir subset-directed administration improved or eliminated CFS symptoms in Group A CFS patients, allowing them to return to normal life. EBV, HCMV, and HHV6 single and multiple herpesvirus Group A CFS patients were identified and responded equally well. Different patient populations in other CFS clinics may have varying percentages of these three herpesviruses. Valacyclovir and valganciclovir as administered here were safe. Single and multiple infected Group A CFS patients responded. An initial Jarisch-Herxheimer response at the start of antiviral medication initiates successful treatment. The higher the baseline EIPS, the better the prognosis. The long-term recovery of Group A CFS patients reported in this study is unprecedented. These remarkable results are dependent upon the careful diagnostic panel outlined here under Methods. We emphasize that the serologic antigens utilized for antibody assays of B. burgdorferi are identical to those used by the US Centers for Disease Control.

It is unclear whether XMRV gamma retrovirus infection initiates the immunosuppression which may be responsible for CFS. Nevertheless, specific herpesvirus antiviral treatment reversed CFS illness in 79 of 106 Group A CFS patients. Earlier studies suggesting a herpesvirus CFS causation had not used either the diagnostic criteria or long-term herpesvirus therapy, nor had previous herpesvirus CFS research separated groups A and B CFS which is critical to these results. $^{4,5}$

Cardiac muscle disease, syncope, chest pain, positive tilt table tests, tachycardias at rest, decreased left ventricular ejection fraction, and left ventricular dilatation improved and/ or disappeared with antiviral treatment. The abnormal HM is a reliable biomarker of CFS cardiac disease. The EIPS is integral to follow severity and reversal of CFS illness.

Questions about the pathogenesis of CFS remain. There is a preponderance of tick-borne $B$. burgdorferi, and Anaplasma and Babesia coinfections in Group B CFS patients. Studies of possible antibiotics in patients with suspected chronic Lyme disease need to consider the possibility of an unrecognized presence of Group B herpesvirus CFS. Does herpesvirus CFS inhibit a class-switch transformation from IgM to IgG in B. burgdorferi infection? Elevated IgG HCMV titers with no IgM HCMV titers are common in human immunodeficiency virus (HIV)-acquired immunodeficiency syndrome (AIDS) patients, but AIDS patients have HCMV DNA in their blood by polymerase chain reaction. Does nonpermissive latent herpesvirus replication in CFS inhibit classic IgM/IgG class-switch interchange for the involved CFS herpesvirus? Meta-analysis of multiple randomized CFS therapeutic studies have determined a $17 \%$ placebo response. ${ }^{39}$ Graded exercise and psychotherapy alleviate some CFS symptoms, ${ }^{6,7}$ but neither therapy approaches the results of this report. The data here suggest exercise may be tolerated at EIPS $>7$. A CFS patient (EIPS value $\leq 5$ ) with a posttreatment EIPS value of 6 lives a normal life with only a short midday nap. The present data are remarkable considering that these CFS patients had been ill for a mean of 4.8 years before antiviral therapy was begun. The mean duration of antiviral therapy for Group A CFS patients was 2.4 years. Both valacyclovir and valganciclovir were equally effective in single or multiple herpesvirus CFS subsets.

In these CFS patients, herpesvirus antigenemia, viremia, and polymerase chain reactions in CFS tissues and bloods were negative. ${ }^{4,15}$ The CFS nonpermissive abortive herpesvirus paradigm postulates mRNA to middle or late EBV, HCMV, and HHV6 genes is present in the blood macrophages and lymphocytes of CFS patients. The presence of IgM serum antibodies to the nonstructural tegument middle-gene products HCMV p52 and $\mathrm{HCMV} \mathrm{CM}_{2}$ in HCMV CFS is consistent with this hypothesis. ${ }^{24,25} \mathrm{CFS}$ is a result of persistent single or multiple EBV, HCMV and/or HHV6 infections(s), categorized as a two-group complex illness without coinfection (Group A) or with coinfections (Group B). These data show that $74.5 \%$ of 106 Group A CFS patients returned to near-normal to normal lives after long-term herpesvirus subset-directed antiviral therapy.

Finally, the rationale for prolonged antiviral treatment requires discussion. This CFS herpesvirus paradigm is that herpesviruses (EBV, HCMV, HHV6) are constantly attempting to produce virulent complete virus as early, middle, and late gene product in progression, and, ultimately, cytopathic effects, and an inflammatory cytolysis of the affected cells. Progeny-complete herpesvirus then continues to infect new host cells. Similarly, the host-immune system attempts to inhibit herpesvirus replication and induce silent virus latency as intranuclear episomes with no viral gene products. In CFS, we hypothesize there is immediate-early gene and early gene expression, dysregulation of host cell functions, and cell cycle progression leading ultimately to noninflammatory apoptosis, such as that observed at cardiac biopsy. ${ }^{15}$ This proposed CFS process produces no viral DNA, no viral antigenemia, and no virion maturation. ${ }^{40}$ The CFS patient cannot successfully achieve herpesvirus latency. Valacyclovir (EBV) and valganciclovir (HCMV, HHV6) inhibit viral DNA polymerases. The long duration 
of antiviral therapy responds to the ongoing opposing forces, ie, virus induction-infected cellular destruction versus cellular survival by an effective immune response. We continue valacyclovir/valganciclovir until the EIPS is $\geq 7$. If no further antiviral therapy is necessary, the CFS patient now independently maintains herpesvirus latency. The biologic parameters to be followed in this ongoing process are critical in our diagnostic panel and are described fully under Methods. These are EBV VCA, IgM (returns to negative), EBV, EA-D (decreases and returns to negative), HCMV IgM p52 and IgM CM (return to normal), and HM abnormalities (eg, T-waves normalize and tachycardias disappear). This thesis predicts that mRNA to intermediateearly herpesvirus genes is circulating in mononuclear cells in the blood of CFS patients, but this mRNA is not present in healthy subjects.

\section{Acknowledgments}

This research was presented in part at the Third International Myalgic Encephalomyelitis Conference on 23 May 2008 in London, England, and at the Eighth International Conference of Anticancer Research, 17 October 2008 in Kos, Greece. More information is available at: http://www.treatmentcenterforcfs.com. We acknowledge gratefully Deanna Mason, security officer, for these data and Deborah McNeilance, transcriptionist. We thank Jeffrey Band, Director of Infectious Diseases and Epidemiology, William Beaumont Hospital, and Ann Cavanagh, Communications Director at the Dr A Martin Lerner CFS Foundation for critical review of this manuscript.

\section{Disclosure}

There was no grant support or pharmaceutical involvement in this research. Drs Lerner, Beqaj, and Fitzgerald have financial interests in CFS LLC which owns patents for diagnosis and treatment of CFS with antiviral agents.

\section{References}

1. Holmes GP, Kaplan JE, Gantz NM, et al. Chronic fatigue syndrome: A working case definition. Ann Intern Med. 1988:108;387-389.

2. Fukuda K, Straus SE, Hickie I, Sharp MC, Dobbins JG, KomaroffA. The chronic fatigue syndrome: A comprehensive approach to its definition and study. International Chronic Fatigue Syndrome Study Group. Ann Intern Med. 1994;121:953-959.

3. Jason LA, Richman JA, Rademaker AW, et al. A community-based study of chronic fatigue syndrome. Arch Intern Med. 1999;159:2129-2137.

4. Straus SE. Chronic fatigue syndrome. In: Kasper DL, Braunwald E, Fauci AS, Hauser SL, Longo DL, Jameson JL, editors. Harrison's Principles of Internal Medicine. 16th ed. New York, NY: McGraw Hill Publishers; 2004.

5. Soto NE, Straus SE. Chronic fatigue syndrome and herpesviruses: The fading evidence. Herpes. 2000;7(2):46-50.
6. Stulemeijer M, deJong LW, Fiselier TJ, Hoogveld SW, Bleijenberg G. Cognitive behavior therapy for adolescents with chronic fatigue syndrome: Randomized controlled trial. BMJ. 2005;330:14. Erratum in: BMJ 2005;330:820

7. Wallman KE, Morton AR, Goodman C, Grove R. Randomized controlled trial of graded exercise in chronic fatigue syndrome. Med J Aust. 2004; 180:444-448.

8. Lombardi VC, Ruscetti FW, Das Gupta J, et al. Detection of an infectious retrovirus XMRV in blood cells of patients with chronic fatigue syndrome. Science. 2009;326:585-589.

9. Schlaberg R, Choe DJ, Brown KR, Thaker HM, Singh IR. XMRV is present in malignant prostatic epithelium and is associated with prostate cancer, especially high-grade tumors. Proc Natl Acad Sci U S A. 2009;10:16351-16356.

10. McClure $\mathrm{M}$, Wessely $\mathrm{S}$. Chronic fatigue syndrome and human retrovirus XMRV. BMJ. 2010:340;c1099.

11. Rowe PC, Bou-Holaigah I, Kan JS, Calkins H. Is neurally mediated hypotension an unrecognised cause of chronic fatigue syndrome? Lancet. 1995;45:623-624.

12. Lerner AM, Lawrie-Hoppen C, Dworkin HJ. Repetitively negative changing T-waves at 24-h electrocardiographic monitors in patients with the chronic fatigue syndrome. Left ventricular dysfunction in a cohort. Chest. 1993;104:1417-1420.

13. Peckerman A, LaManca JJ, Dahl KA, et al. Abnormal impedance cardiography predicts symptom severity in chronic fatigue syndrome. Am J Med Sci. 2003:326;55-60.

14. Dworkin HJ, Lawrie C, Bohdiewiez P, Lerner AM. Abnormal left ventricular myocardial dynamics in eleven patients with the chronic fatigue syndrome. Clin Nucl Med. 1994:19;657-677.

15. Lerner AM, Goldstein J, Chang $\mathrm{CH}$, et al. Cardiac involvement in patients with the chronic fatigue syndrome as documented with Holter and biopsy data in Birmingham, Michigan. Inf Dis Clin Pract. 1997:6;327-333.

16. Lerner AM, Dworkin HJ, Sayyed T, et al. Prevalence of abnormal cardiac wall motion in the cardiomyopathy associated with incomplete multiplication of EBV and/or CMV in patients with chronic fatigue syndrome. In Vivo. 2004;18:417-424.

17. Klimas NG, Salvato FR, Morgan R, Fletcher MA. Immunological abnormalities in chronic fatigue syndrome. J Clin Microbiol. 1990:28;1403-1410.

18. Tiev KP, Demettre E, Ercolano P, Bastidel L, Lebleu B, Cabane J. RNase levels in peripheral blood mononuclear cells: 37-kilodalton/83kilodalton isoform ratio is a potential test for chronic fatigue syndrome. Clin Diag Lab Immunol. 2005:12;1259-1260.

19. McDermott C, Richards SC, Thomas PW, Montgomery J, Lewith G. A placebo-controlled, double-blind, randomized controlled trial of a natural killer cell stimulant (BioBran MGN-3) in chronic fatigue syndrome. QJM. 2006:99;461-468.

20. Brooks J, Roberts N, Whitehouse G, Majeed T. Proton magnetic resonance spectroscopy and morphometry of the hippocampus in chronic fatigue syndrome. Br J Radiol. 2000:73;1206.

21. Kerr J R, Petty R, Burke B, et al. Gene expression subtypes in patients with chronic fatigue syndrome/myalgic encephalomyelitis. J Infect Dis. 2008:197; 1171-1184.

22. Lerner AM, Zervos M, Dworkin HJ, Chang CH, O’Neill W. Hypothesis: A unified theory of the cause of the chronic fatigue syndrome. Infect Dis Clin Pract. 1997:6;239-243.

23. Lerner AM, Beqaj SH, Deeter RG, Fitzgerald JT. IgM serum antibodies to Epstein-Barr virus are uniquely present in a subset of patients with chronic fatigue syndrome. In Vivo. 2004:18;101-106.

24. Lerner AM, Beqaj SH, Deeter RG, et al. IgM serum antibodies to human cytomegalovirus nonstructural gene products p52 and CM (UL44 and UL57) are uniquely present in a subset of patients with chronic fatigue syndrome. In Vivo. 2002:16;153-160.

25. Beqaj SH, Lerner AM, Fitzgerald JT. Immunoassay with cytomegalovirus early antigens from gene products p52 and CM (UL44 and UL57) detects active infection in patients with chronic fatigue syndrome. J Clin Pathol. 2008:61;623-626. 
26. Streblow DN, Varnum SM, Smith RD, et al. A proteomics analysis of human cytomegalovirus particles. In: Reddehase MJ, editor. Cytomegalovirus, Molecular Biology and Immunology. Norfolk, UK: Caister Academic Press; 2006.

27. Lerner Am, Beqaj SH, Fitzgerald JT. Validation of the Energy Index Point Score to serially measure degree of disability in patients with chronic fatigue syndrome. In Vivo. 2008:22;799-802.

28. Lerner AM, Zervos M, Dworkin HJ, et al. New cardiomyopathy: Pilot study of intravenous ganciclovir in a subset of the chronic fatigue syndrome. Infect Dis Clin Pract. 1997;6:110-117.

29. Lerner AM, Beqaj SH, Deeter RG, et al. A six-month trial of valacyclovir in the Epstein-Barr virus subset of chronic fatigue syndrome: Improvement in left ventricular function. Drugs of Today. 2002:38(8):549-561.

30. Lerner AM, Beqaj SH, Deeter RJ, Fitzgerald JT. Valacyclovir treatment in Epstein-Barr virus subset chronic fatigue syndrome: Thirty-six month follow-up. In Vivo. 2007:21;707-713.

31. Komaroff AL. Is human herpesvirus 6 a trigger for chronic fatigue syndrome? J Clin Virol. 2006:37;S39-S46.

32. Weller S, Blum MR, Doucette M, et al. Pharmacokinetics of the acyclovir pro-drug valacyclovir after escalating single- and multipledose administration to normal volunteers. Clin Pharmacol Ther. 1993:54;595-605.

33. Tyring SK. Advances in the treatment of herpesvirus infection: The role of famciclovir. Clin Ther. 1998;20:661-670.
34. Purifoy DJ, Beauchamp LM, de Miranda P, et al. Review of research leading to new anti-herpesvirus agents in clinical development: Valacyclovir hydrochloride (256U, the L-valyl ester of acyclovir) and 882C, a specific agent for Varicella Zoster virus. J Med Virol. 1993: Suppl 1;139-145.

35. Straus SE. Epstein-Barr virus and human herpesviruses 6 and 7. In: Galasso GT, Whitley RJ, Merigan TC, editors. Antiviral Agents and Human Viral Diseases. 4th ed. Wickford, RI: Lippincott-Raven Publishers; 1997.

36. Wormser GP, Dattwyler RJ, Shapiro ED, et al. The clinical assessment, treatment, and prevention of Lyme disease, human granulocytic anaplasmosis and babesiosis: Clinical practice guidelines by the Infectious Diseases Society of America. Clin Infect Dis. 2006:43:1089-134. Erratum in: Clin Infect Dis. 2007;45:941.

37. Kaplan EL. Rheumatic fever. In: Kasper DL, Iauci AS, Longo DL, Braunwald E, Hauser SL, Jameson JL, editors. Harrison's Principles of Internal Medicine. 16th ed. New York, NY: McGraw Hill Publishers; 2005.

38. Heng HH. The conflict between complex systems and reductionism. JAMA. 2008:300;1580-1581.

39. Cho HJ, Hotopf M, Wessely S. The placebo response in the treatment of chronic fatigue syndrome: A systemic review and meta-analysis. $A d v$ Psychosom Med. 2005:67;301-13.

40. Landolfo S, Gariglio M, Gribaudo G, Lembo D. The human cytomegalovirus. Pharmacol Ther. 2003:98;269-297.
Virus Adaptation and Treatment

\section{Publish your work in this journal}

Virus Adaptation and Treatment is an international, peer-reviewed open access journal focusing on the study of virology, viral adaptation and the development and use of antiviral drugs and vaccines to achieve improved outcomes in infection control and treatment. The journa welcomes original research, basic science, clinical \& epidemiological

\section{Dovepress}

studies, reviews \& evaluations, expert opinion and commentary, case reports and extended reports. The manuscript management system is completely online and includes a very quick and fair peer-review system, which is all easy to use. Visit http://www.dovepress.com/ testimonials.php to read real quotes from published authors. 